\title{
A STUDY OF
}

\section{THE ENGLISH APOTHECARY FROM 1660 TO 1760}

\author{
by \\ JUANITA G. L. BURNBY
}

(Medical History, Supplement No. 3)

\section{LONDON \\ WELLCOME INSTITUTE FOR THE HISTORY OF MEDICINE} 1983 


\section{CONTENTS}

Introduction

\section{Chapters}

I The place of the apothecary in the evolution of medical practice 4

II Job description $\quad 14$

$\begin{array}{ll}\text { III The apothecary as progenitor } & 24\end{array}$

IV The apothecary as man of science $\quad 62$

V The education and cultural interests of the apothecary 79

VI Status and social position $\quad 92$

$\begin{array}{ll}\text { Conclusion } & 113\end{array}$

$\begin{array}{ll}\text { Index } & 117\end{array}$ 


\section{A STUDY OF THE ENGLISH APOTHECARY FROM 1660 TO 1760}

(Medical History, Supplement No. 3, 1983) 


\section{DEDICATION}

To the memory of my mother, Amy Kathleen Thomas. 
Published 1983 by the Wellcome Institute for the History of Medicine, 183 Euston Road, London NWI 2BP.

(C) Wellcome Institute for the History of Medicine, 1983.

ISBN 0854840435

ISSN 002572733

Supplements to Medical History may be obtained at the Wellcome Institute, or by post from Science History Publications Ltd, Halfpenny Furze, Chalfont St Giles, Bucks HP8 4NR, England.

Printed by the Wellcome Foundation Limited, Print and Packaging Division (Crewe). 


\section{ACKNOWLEDGMENTS}

It is impossible to name more than a few of those who have helped me over the course of many years, but I would like particularly to acknowledge my debt to Miss Margaret Mackenzie who set me on the path of serious historical research, and to Miss Barbara Fenwick who has sat in record offices for many long hours transcribing material for me. Dr Jessie Ridge and Mr F. H. Rawlings have been so generous as to allow me access to their unpublished material, which was extremely useful; whilst the help, encouragement, and stimulating exchange of ideas with Dr Edwin Clarke and Dr Douglas Whittet have proved invaluable. I am very conscious of the debt I owe to the editorial staff of Medical History, in particular to Mrs J. Runciman whose patience and ingenuity in dealing with problems seem to be inexhaustible.

To my husband I can but say "Thank you" and that without you none of this work would have been possible.

\section{NOTE}

It should be noted that dates of days from the 1st January to the 24th March prior to 1752 are given according to the moden calendrical style, as if the year began on the 1st January. 